\title{
A Dendrimer Approach to High-Spin Polycarbenes. Conversion of Connectivity from Disjoint to Non-Disjoint by Perturbation of Nonbonding Molecular Orbital Coefficients
}

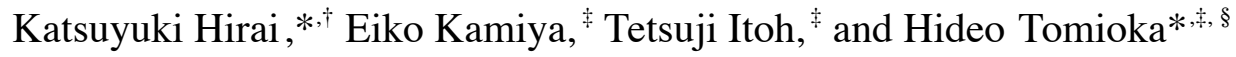 \\ ${ }^{\dagger}$ Instrumental Analysis Facilities, Life Science Resear ch Center, and ${ }^{\ddagger}$ Chemistry \\ Department for Materials, Faculty of Engineering, Mie University , Tsu, Mie 514-8507, \\ Japan, and ${ }^{\S}$ Department of Applied Chemistry, Aichi Institute of Technology, Toyota, \\ Aichi 470-0392, Japan
}

\section{Supporting Information}

General Methods. ${ }^{1} \mathrm{H}$ - and ${ }^{13} \mathrm{C}-\mathrm{NMR}$ spectra were recorded on JEOL JNMAC300FT/NMR spectrometer in $\mathrm{CDCl}_{3}$ with $\mathrm{Me}_{4} \mathrm{Si}$ as an internal reference. IR spectra were measured on a JASCO-Herschel FT/IR-600H spectrometer, and UV-vis spectra were recorded on a JASCO CT -560 spectrophotometer. The mass spectra were recorded on a JEOL JMS-600H mass spectrometer. Gel permeation chromatography (GPC) was carried out on a JASCO, PU-1586 instrument using UV -1570 as a detector. The GPC column was a Shodex H-2001. Column chromatography was performed on silica gel (Merck for dry column chromatography) or aluminum oxide (ICN, neutral activity grade $\mathrm{I}$, in activated with $5 \% \mathrm{H}_{2} \mathrm{O}$ ).

Unless otherwise noted, all the reagents employed in this study are commercial products and used after standard purification. 1,4-Dioxane and 2methyltetrahydrofuran (2-MTHF) were purified by distillation from sodium/benzophenone and triethylamine was from calcium hydride.

\section{Materials.}

Preparation of Bis(4-iodo-2,6-dimethylphenyl)diazomethane (1) The replacement reaction of bromine with iodine was carried out according to the methods reported by Buchwald. ${ }^{1}$ To a mixture of ethyl $N$-\{bis(4-bromo-2,6dimethylphenyl)methyl carbamate $^{2}(672 \mathrm{mg}, 1.4 \mathrm{mmol})$, sodium iodide $(1.0 \mathrm{~g}, 6.7$ 
mmol), and copper(I) iodide ( $27 \mathrm{mg}, 0.14 \mathrm{mmol}$ ), anhydrous 1,4-dioxane ( $3 \mathrm{~mL}$ ) was added under argon atmosphere, and this mixture was stirred for $5 \mathrm{~min}$. To the mixture, $N, N^{\prime}$-dimethylethylenediamine (30 mL, $0.28 \mathrm{mmol}$ ) was added, and the mixture was refluxed for 40 hours. After cooling, sodium bromide was removed from the reaction mixture by filtration and washed with chloroform, and the filtrate was evaporated.

Ethyl $N$-\{bis(4-iodo-2,6-dimethylphenyl)methyl\}carbamate was obtained as a white solid (650 mg, 98\%): mp $152.7-155.6{ }^{\circ} \mathrm{C}, 300 \mathrm{MHz}{ }^{1} \mathrm{H}-\mathrm{NMR}\left(\mathrm{CDCl}_{3}, \mathrm{ppm}\right) \delta 7.32$ (s, $4 \mathrm{H}), 6.22(\mathrm{~d}, J=8.0 \mathrm{~Hz}, 1 \mathrm{H}), 4.92(\mathrm{~d}, J=8.0 \mathrm{~Hz}, 1 \mathrm{H}), 4.15(\mathrm{q}, J=7.0 \mathrm{~Hz}, 2 \mathrm{H}), 2.11$ $(\mathrm{s}, 12 \mathrm{H}), 1.25(\mathrm{t}, J=7.0 \mathrm{~Hz}, 3 \mathrm{H}) ; 75.5 \mathrm{MHz}{ }^{13} \mathrm{C}-\mathrm{NMR}\left(\mathrm{CDCl}_{3}, \mathrm{ppm}\right) \delta 155.2,133.8$, 130.0, 93.0, 61.3, 54.5, 21.0, 14.7; EI-MS m/z (rel intensity) 564 (M+1, 27), $563\left(\mathrm{M}^{+}\right.$, 94), 332 (53), 258 (100); HRMS calcd for $\mathrm{C}_{20} \mathrm{H}_{23} \mathrm{NO}_{2} \mathrm{I}_{2}$ 562.9819, found $\mathrm{m} / z$, 562.9887.

To a stirred and cooled solution of ethyl $N$-\{bis(4-iodo-2,6dimethylphenyl)methyl\}carbamate $(993 \mathrm{mg}, 1.7 \mathrm{mmol})$ in acetic anhydride $(30 \mathrm{~mL})$ and acetic acid $(15 \mathrm{~mL})$ was added sodium nitrite $(2.4 \mathrm{~g}, 35 \mathrm{mmol})$ in portions at $0{ }^{\circ} \mathrm{C}$ over a period of $0.5 \mathrm{~h}$ and the mixture was stirred for 13 hours at room temperature after addition was complete. The mixture was poured into ice and was extracted with diethyl ether. The organic layer was washed with aqueous sodium carbonate, dried over anhydrous sodium sulfate, and concentrated under reduced pressure to give ethyl $N$-nitroso- $N$-\{bis(4-iodo-2,6-dimethylphenyl)methyl\}carbamate as a viscous yellow liquid (1.0 g, 99\%): $300 \mathrm{MHz}{ }^{1} \mathrm{H}-\mathrm{NMR}\left(\mathrm{CDCl}_{3}, \mathrm{ppm}\right) \delta 7.31(\mathrm{~s}, 4 \mathrm{H}), 6.68(\mathrm{~s}, 1 \mathrm{H}), 4.37$ (q, $J=7.2 \mathrm{~Hz}, 2 \mathrm{H}), 1.89(\mathrm{~s}, 12 \mathrm{H}), 1.28(\mathrm{t}, J=7.2 \mathrm{~Hz}, 3 \mathrm{H})$.

To a stirred solution of ethyl $N$-nitroso- $N$ - $\{$ bis(4-iodo-2,6dimethylphenyl)methyl\}carbamate $(75 \mathrm{mg}, 0.13 \mathrm{mmol})$ in dry tetrahydrofuran $(7 \mathrm{~mL})$ was added potassium tert-butoxide (58 $\mathrm{mg}, 0.52 \mathrm{mmol}$ ) at $-15{ }^{\circ} \mathrm{C}$ under argon atmosphere. After being stirred for 14 hours, the reaction mixture was extracted with ether, and the organic layer was washed with water, dried over anhydrous sodium sulfate, and concentrated under reduced pressure to leave a crude product that was purified by column chromatography (aluminum oxide deactivated with $5 \%$ water, $n$ hexane at $0{ }^{\circ} \mathrm{C}$ ), followed by GPC ( 15 cycle, chloroform, monitored at $300 \mathrm{~nm}$ ) to give bis(4-iodo-2,6-dimethylphenyl) diazomethane (1) as red solids (44 mg, 29\%): $\mathrm{mp}$ 133.9 - $135.6{ }^{\circ} \mathrm{C}$ (dec.); $300 \mathrm{MHz}{ }^{1} \mathrm{H}-\mathrm{NMR}\left(\mathrm{CDCl}_{3}, \mathrm{ppm}\right) \delta 7.42$ (s, 4H), 2.04 (s, 
$12 \mathrm{H}) ; 75.5 \mathrm{MHz}{ }^{13} \mathrm{C}-\mathrm{NMR}\left(\mathrm{CDCl}_{3}, \mathrm{ppm}\right) \delta 139.1,137.7,128.7$, 93.0, 58.2, 20.4; IR $\left(\mathrm{NaCl}, \mathrm{cm}^{-1}\right) 2045\left(v_{\mathrm{C}=\mathrm{N} 2}\right)$.

Preparation of Pentakis(diazo) Compound (3 a) To a mixture of 3,5-bis[4\{diazo(4-tert-butyl-2,6-dimethylphenyl)methyl \}-3,5-

dibromophenylethynyl ]phenylacetylene ${ }^{3}(2,12.0 \mathrm{mg}, 12.0 \mathrm{mmol})$, bis(4-iodo-2,6dimethylphenyl)diazomethane $(\mathbf{1}, \quad 3.0 \quad \mathrm{mg}, \quad 6.0 \mathrm{mmol})$, dichloro bis(triphenylphosphine)palladium(II) $(0.40 \mathrm{mg}, 0.60 \mathrm{mmol})$, and copper( I) iodide $(0.2$ $\mathrm{mg}, 1.0 \mathrm{mmol})$ was added anhydrous triethylamine $(1 \mathrm{~mL})$ at room temperature under an atmosphere of $1: 1$ mixture of nitrogen and hydrogen. The mixture was stirred 12 hours at $40{ }^{\circ} \mathrm{C}$, evaporated, passed through a short alumina column (aluminum oxide deactivated with $5 \%$ water, chloroform at $0{ }^{\circ} \mathrm{C}$ ), and purified by GPC ( 5 cycles, chloroform, monitored at $300 \mathrm{~nm}$ ). Pentakis(diazo) compound (3a) was obtained as red solids (7.4 mg, 54\%): mp 137.0 - $138.2{ }^{\circ} \mathrm{C}$ (dec.); $300 \mathrm{MHz}{ }^{1} \mathrm{H}-\mathrm{NMR}\left(\mathrm{CDCl}_{3}\right.$, ppm) $\delta 7.74(\mathrm{~s}, 8 \mathrm{H}), 7.63(\mathrm{~d}, J=1.5 \mathrm{~Hz}, 4 \mathrm{H}), 7.59(\mathrm{t}, J=1.5 \mathrm{~Hz}, 2 \mathrm{H}), 7.28(\mathrm{~s}, 4 \mathrm{H})$, $7.09(\mathrm{~s}, 8 \mathrm{H}), 2.18(\mathrm{~s}, 24 \mathrm{H}), 2.13(\mathrm{~s}, 12 \mathrm{H}), 1.31(\mathrm{~s}, 36 \mathrm{H}) ; 75.5 \mathrm{MHz}{ }^{13} \mathrm{C}-\mathrm{NMR}\left(\mathrm{CDCl}_{3}\right.$, ppm) $\delta 151.0,137.5,137.3,135.9,134.6,134.0,132.8,132.2,130.0,126.0,124.8$, $124.7,124.4,123.8,123.3,121.4,91.0,90.4,87.9,87.6,63.8,59.3,34.3,31.3,21.2$, 20.7; IR $\left(\mathrm{NaCl}, \mathrm{cm}^{-1}\right) 2055\left(v_{\mathrm{C}=\mathrm{N} 2}\right), 2214\left(v_{\mathrm{C} \equiv \mathrm{C}}\right)$.

ESR Measurements. The diazo compound was dissolved in 2 -MTHF $\left(4.0 \times 10^{-3}\right.$ M) and the solution was degassed in a quartz cell by five freeze-degas-thaw cycles. The sample was cooled in an optical transmission E SR cavity at $77 \mathrm{~K}$ and irradiated with a Halos 500-W high-pressure mercury lamp using a Pyrex filter . ESR spectra were measured on a JEOL JES TE 200 spectrometer (X-band microwave unit, 100 $\mathrm{kHz}$ field modulation). The signal positions were read by the use of a gaussmeter. The temperature was controlled by a 9650 Microprocessor -based Digital Temperature Indicator/Controller. Errors in the measurements of component amplitudes did not exceed $5 \%$, the accuracy of the resonance fields determination was within $\pm 0.5 \mathrm{mT}$.

Low-Temperature UV/vis Spectra. Low-temperature spectra at $77 \mathrm{~K}$ were obtained by using an Oxford variable-temperature liquid-nitrogen cryostat (DN 1704) 
equipped with a quartz outer window and a sapphire inner window . The sample was dissolved in 2-MTHF $\left(7.7 \times 10^{-4} \mathrm{M}\right)$, placed in a long-necked quartz cuvette of $1-\mathrm{mm}$ path length, and degassed thoroughly by repeated freeze-degas-thaw cycles at a pressure near $10^{-5}$ Torr. The cuvette was flame-sealed, under reduced pressure, placed in the cryostat, and cooled to $77 \mathrm{~K}$. The sample was irradiated for several minutes in the spectrometer with a Halos 500-W high-pressure mercury lamp using a Pyrex filter , and the spectral changes were recorded at appropriate time intervals. The spectral changes upon thawing were also monitored by carefully controlling the matrix temperature with an Oxford Instrument Intelligent T emperature Controller (ITC 4).

SQUID Measurements. Magnetic susceptibility data were obtained on a Quantum Design MPMS-2A Superconducting Quantum Interference Device (SQUID) magnetometer/susceptometer. Irradiation with light from an ar gon ion laser (488 nm, Omnichrome 543-150BS) through a flexible optical fiber which passes through the inside of the SQUID sample holder was performed inside the sample room of SQUID apparatus at $5-10 \mathrm{~K}$. One end of the optical fiber was located $40 \mathrm{~mm}$ above the sample cell (capsule) and the other was attached to a coupler for the laser. The bottom part of the capsule $(6 \mathrm{~mm} \times 10 \mathrm{~mm})$ without a cap was used as a sample cell. A $50 \mathrm{~mL}$ of the sample solution ( $0.3 \mathrm{mM})$ in 2-MTHF was placed in the cell, which was held by a straw. The irradiation was carried out until there is no further change of magnetization monitored at $5 \mathrm{~K}$ in a constant field of $5 \mathrm{kOe}$. The magnetization, $M \mathrm{~b}$ and $\mathrm{Ma}$, before and after irradiation was measured at 2.0 and $5.0 \mathrm{~K}$ in a field range $0-$ $50 \mathrm{kOe}$. The plots of the magnetization ( $M=M \mathrm{a}-M \mathrm{~b}$ ) versus the magnetic field were analyzed in terms of the Brillouin function.

\section{References}

(1) Klapars, A.; Buchwald, S. J. Am Chem. Soc. 2002, 124, 14844.

(2) Itoh, T.; Matsuno, M.; Ozaki, S.; Hirai, K.; T omioka, H. J. Phys. Chem. B 2005, 109, 20763.

(3) Itoh, T.; Maemura, T.; Ohtsuka, Y.; Ikari, Y.; Wilt, H.; Hirai, K.; T omioka, H. Eur. J. Org. Chem. 2004, 2991. 

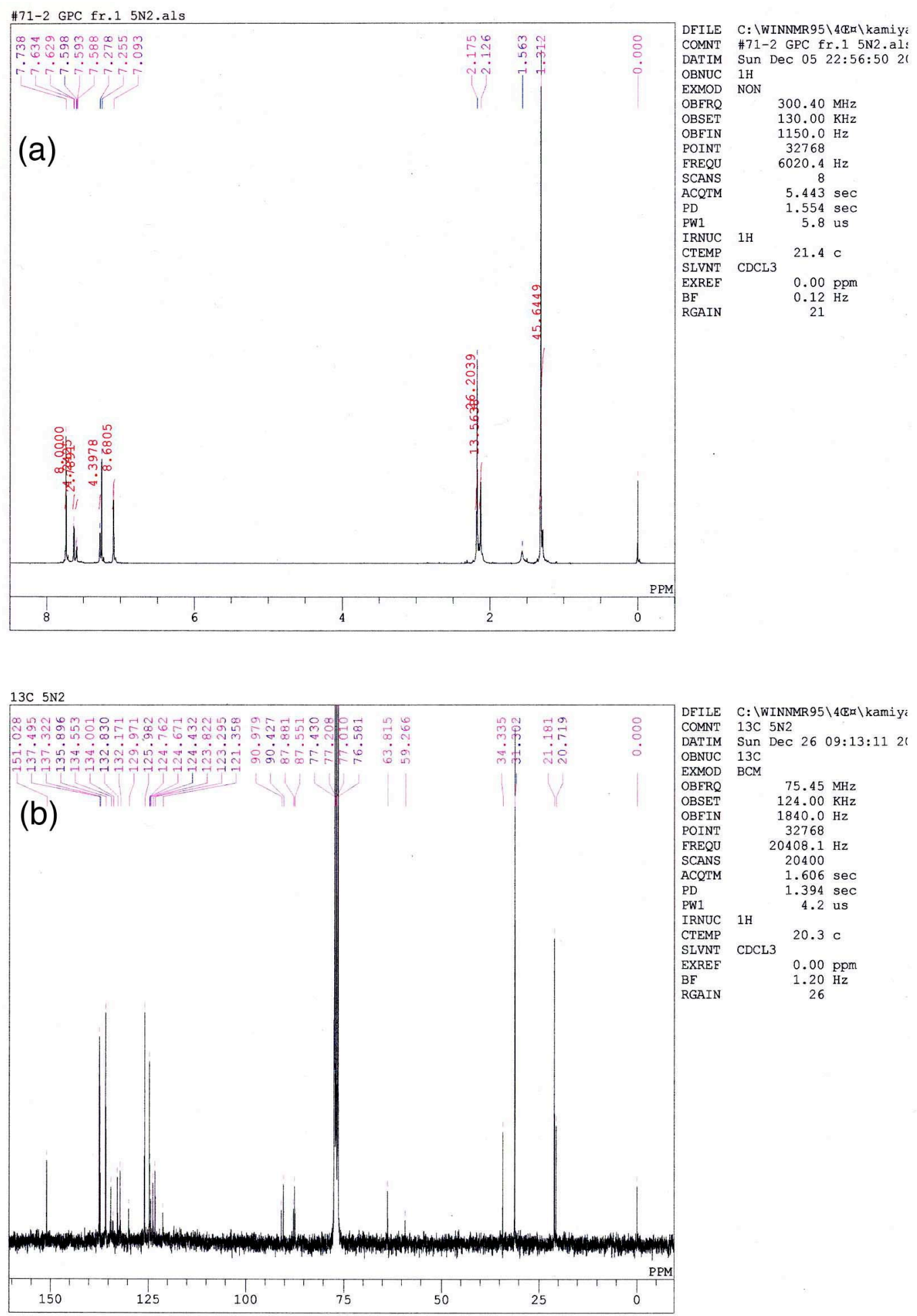
Figure S1. NMR spectra of pentakis(diazo) compound (3a). (a) ${ }^{1} \mathrm{H}-\mathrm{NMR}$. (b) ${ }^{13} \mathrm{C}-$ NMR.

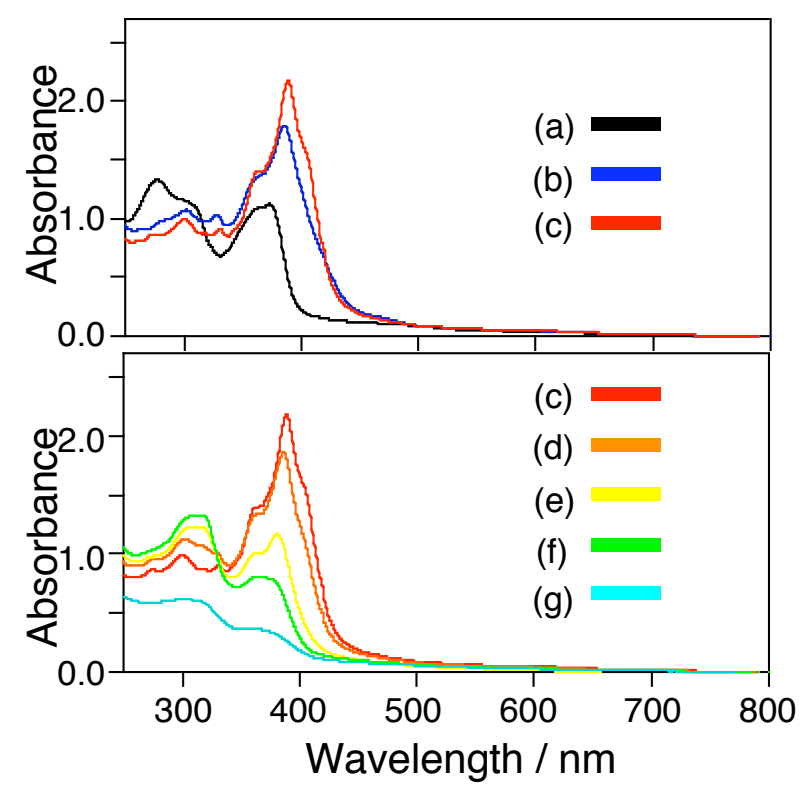

Figure S2. UV-vis spectral changes obtained by irradiation of pentakis(diazo) compound 3a. (a) Spectrum of 3a in 2-methyltetrahydrofuran at 77 K. (b) The same sample after irradiation $(\lambda>300 \mathrm{~nm})$. (c-g) The same sample after thawing to 110 (c), 130 (d), 140 (e), 160 (f), and 300 (g) K.

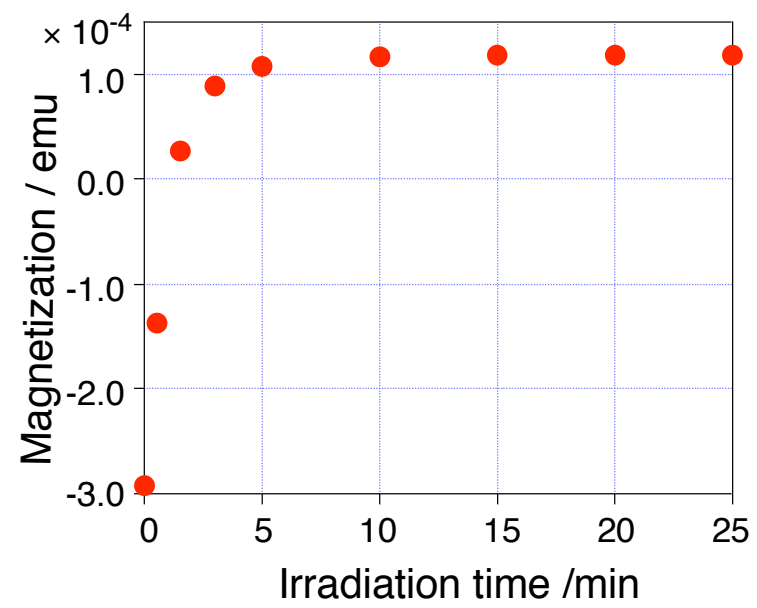

Figure S3. Plot of magnetization as a function of irradiation time observed in the photolysis of 3a in 2-MTHF at $5.0 \mathrm{~K}$ and $5 \mathrm{kOe}$. 


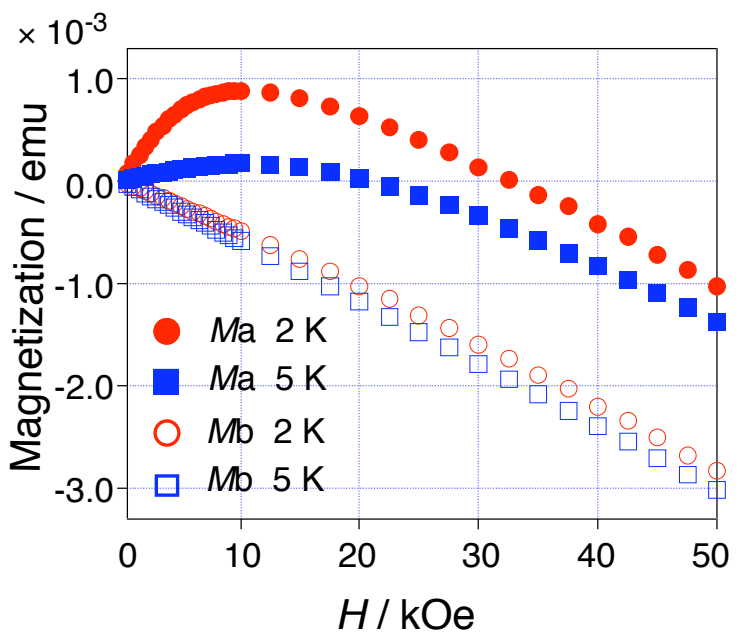

Figure S4. Field dependence of the magnetization of the photoproduct from 3a in a $0.3 \mathrm{mM}$ 2-MTHF matrix measured at 2.0 and $5.0 \mathrm{~K}$. $M \mathrm{~b}$ and $M \mathrm{a}$ refer to the magnetization value before and after irradiation, respectively . 